\title{
Identifying Changes in Source Regions Impacting Speciated Atmospheric Mercury at a Rural Site in the Eastern United States ${ }^{\mathcal{O}}$
}

\author{
IRENE CHENG AND LEIMING ZHANG \\ Air Quality Research Division, Science and Technology Branch, Environment and Climate Change Canada, \\ Toronto, Ontario, Canada \\ MARK CASTRO \\ Appalachian Laboratory, University of Maryland Center for Environmental Science, Frostburg, Maryland \\ HUITING MAO \\ Department of Chemistry, State University of New York College of Environmental Science and Forestry, Syracuse, New York
}

(Manuscript received 16 March 2017, in final form 17 May 2017)

\begin{abstract}
To investigate the effectiveness of emission reductions on the concentrations of gaseous elemental mercury (GEM), gaseous oxidized mercury (GOM), and particulate-bound mercury (PBM) at a rural site in Maryland (MD08), long-term (2005-14) measurements of speciated atmospheric mercury were analyzed using concentration-weighted trajectory (CWT) analysis. CWT results suggested that the number of major source regions contributing to GEM, GOM, and reactive mercury $(\mathrm{RM}=\mathrm{GOM}+\mathrm{PBM})$ over the eastern United States and southeastern Canada declined over time. Across much of these regions, source contributions in 2011-14 decreased by up to $20 \%$ for GEM, by greater than $60 \%$ for GOM, and by $20 \%-60 \%$ for PBM compared to $2006-08$, largely because of the decreases in power-plant mercury emissions since 2009 . Changes in the spatial distribution of the source regions were also observed over time. Increases in source contributions of GEM after 2011 over the northeastern United States and southeastern Canada were predominantly from emission increases in metal and steel production and forest fires. Source contribution increases in PBM were more widespread, which can be attributed potentially to mercury transformation processes in the air or wood combustion rather than industrial sources.
\end{abstract}

\section{Introduction}

Reducing mercury $(\mathrm{Hg})$ emissions from primary sources is a top priority of the Minamata Convention in mitigating global transport of $\mathrm{Hg}$ and its harmful impacts on ecosystems and human health (UNEP 2013). Natural emissions were estimated to be twice as large as anthropogenic emissions on global scales, but a large portion of natural emissions originated from anthropogenic sources through atmospheric deposition of $\mathrm{Hg}$ to the land surface followed by reemission (Pirrone et al.

Supplemental information related to this paper is available at the Journals Online website: http://dx.doi.org/10.1175/JAS-D-170086.s1.

Corresponding author: Leiming Zhang, leiming.zhang@canada.ca
2010; Pacyna et al. 2016). Fossil fuel (mainly coal) combustion and artisanal and small-scale gold mining are major anthropogenic $\mathrm{Hg}$ sources on global scales (UNEP 2013). Policies and actions have been undertaken over the past decade in North America, Europe, and other parts of the world to reduce anthropogenic emissions, especially those from coal-fired power plants (Selin 2014; Giang et al. 2015; Zhang et al. 2016c).

Piney Creek Reservoir in western Maryland, coded as MD08 in the Atmospheric Mercury Network (AMNet) of the National Atmospheric Deposition Program (NADP), is a rural site in the mid-Atlantic United States that is downwind from coal-fired power plants in West Virginia, Ohio, and Pennsylvania. These states are among the top 10 states in the United States for $\mathrm{Hg}$ emissions from power plants (Castro and Sherwell 2015). 
Mercury speciation measurements have been conducted at MD08 to assess the impacts of regional $\mathrm{Hg}$ emissions. In ambient air, the average gaseous elemental $\mathrm{Hg}$ (GEM), gaseous oxidized $\mathrm{Hg}$ (GOM), and particulatebound $\mathrm{Hg}(\mathrm{PBM})$ concentrations were $1.4 \mathrm{ng} \mathrm{m}^{-3}$, $11 \mathrm{pg} \mathrm{m}^{-3}$, and $5.2 \mathrm{pg} \mathrm{m}^{-3}$, respectively, over the 200614 period (Castro and Sherwell 2015). Although the mean air concentrations were comparable to Northern Hemispheric background levels, the site observed over 38000 high-concentration events for 5-min GEM $\left(>1.7 \mathrm{ng} \mathrm{m}^{-3}\right), 1600$ high-concentration events for bihourly or 2-h GOM $\left(>27.3 \mathrm{pg} \mathrm{m}^{-3}\right)$, and 1800 high-concentration events for bihourly or 2-h PBM $\left(>10.7 \mathrm{pg} \mathrm{m}^{-3}\right)$ during 2006-14. There have been significant decreases in the annual-averaged GEM and GOM concentrations and the number of concentration spikes from 2006 to 2014 (Castro and Sherwell 2015). For example, high-concentration GEM events decreased from 12938 in 2006 to 1332 in 2014. Annual dry deposition of oxidized $\mathrm{Hg}$ at MD08 was $50 \%$ lower in 2013-14 compared to 2006-07, while wet deposition declined by $20 \%$ from the period $2006-08$ to 2009-14 (Zhang et al. 2016b). These declines have been attributed to emissions control policies in the United States, such as the Clean Air Interstate Rule (CAIR) and Mercury and Air Toxics Standards (MATS). A source apportionment study analyzing back-trajectory frequencies at Beltsville, Maryland, suggests that the effects of mercury emissions on receptor concentrations have changed over time because of emissions reductions from power plants (Ren et al. 2016). To assess the effectiveness of the emissions control on a larger scale, source apportionment studies on long-term data need to be conducted at more locations. Previous findings may also be dependent on the source apportionment method. Other factors besides power-plant $\mathrm{Hg}$ emissions, such as surface temperatures and forest fire emissions, could also impact receptor concentrations over time.

In this study, an assessment of $\mathrm{Hg}$ emissions reductions in North America (Canada and the United States) on speciated atmospheric $\mathrm{Hg}$ at MD08 was carried out using the concentration-weighted trajectory (CWT) method. The CWT method and other similar variations of this approach have been applied to speciated atmospheric $\mathrm{Hg}$ at various receptor sites in Canada, the United States, Mexico, South Korea, and China to determine the source regions impacting receptor concentrations (Han et al. 2007; Rutter et al. 2009; Fu et al. 2012; Cheng et al. 2013; Lee et al. 2014; Ren et al. 2016). This study applied the CWT method to 9 years (2005-14) of speciated atmospheric $\mathrm{Hg}$ data, which allowed us to analyze the change in source regions contributing to this site over a decade. The results were examined closely with spatiotemporal trends in $\mathrm{Hg}$ point-source emissions, particularly power-plant $\mathrm{Hg}$ emissions, as well as surface temperatures and forest fire emissions.

\section{Methods}

\section{a. Mercury measurements}

In this study, the speciated atmospheric $\mathrm{Hg}$ concentration data presented in Castro and Sherwell (2015) were analyzed. The data were collected from August 2005 through 2014, except 2012 because of a lack of funding. GEM, GOM, and PBM $(<2.5 \mu \mathrm{m})$ were measured at MD08 in western Maryland $\left(39^{\circ} 42^{\prime} 19.16^{\prime \prime} \mathrm{N}\right.$, $79^{\circ} 00^{\prime} 45.1^{\prime \prime} \mathrm{W}, 770 \mathrm{~m}$ MSL) using the Tekran speciation system. All measurements, calibrations, and maintenance were made using the standard operating procedures of the NADP/AMNet (Gay et al. 2013). MD08 is a rural site predominantly made up of deciduous forests and agricultural areas. Most of the $\mathrm{Hg}$ emissions are transported from adjacent states, including West Virginia, Ohio, and Pennsylvania (Fig. 1) and are from power plants (Fig. S1 of the supplemental material). These regions are in the prevailing wind directions of MD08, with West Virginia in the southwest, Ohio in the west, and Pennsylvania in the northwest directions. There are also small power-plant mercury sources in eastern Maryland. Based on previous results, winds from the west to northwest had the highest concentrations of GOM and PBM (Castro and Sherwell 2015).

\section{b. Concentration-weighted trajectory method}

There are several approaches that integrate backtrajectory modeling and receptor air pollutant concentrations to predict the spatial distribution of source regions. These include CWT, potential source contribution function (PSCF), and other trajectory residencetime methods, which have been previously reviewed (Watson et al. 2008; Kabashnikov et al. 2011; Cheng et al. 2015; Hopke 2016). This study adopted the CWT model because of the pairing of high sampling resolution concentrations and back-trajectory data [Eq. (1)]:

$$
P_{i j}=\frac{\sum_{l=1}^{L} c_{l} \tau_{i j l}}{\sum_{l=1}^{L} \tau_{i j l}},
$$

where $P_{i j}$ represents the source strength of a $0.5^{\circ} \times 0.5^{\circ}$ grid cell $(i, j)$ (Jeong et al. 2011; Kabashnikov et al. 2011; Cheng et al. 2013). This parameter quantifies the contribution of a particular source region to receptor concentrations. In this study, $c_{l}$ is the 2-h concentration of GEM, $\mathrm{GOM}, \mathrm{PBM}$, or reactive $\mathrm{Hg}(\mathrm{RM} ; \mathrm{RM}=\mathrm{GOM}+\mathrm{PBM})$ 


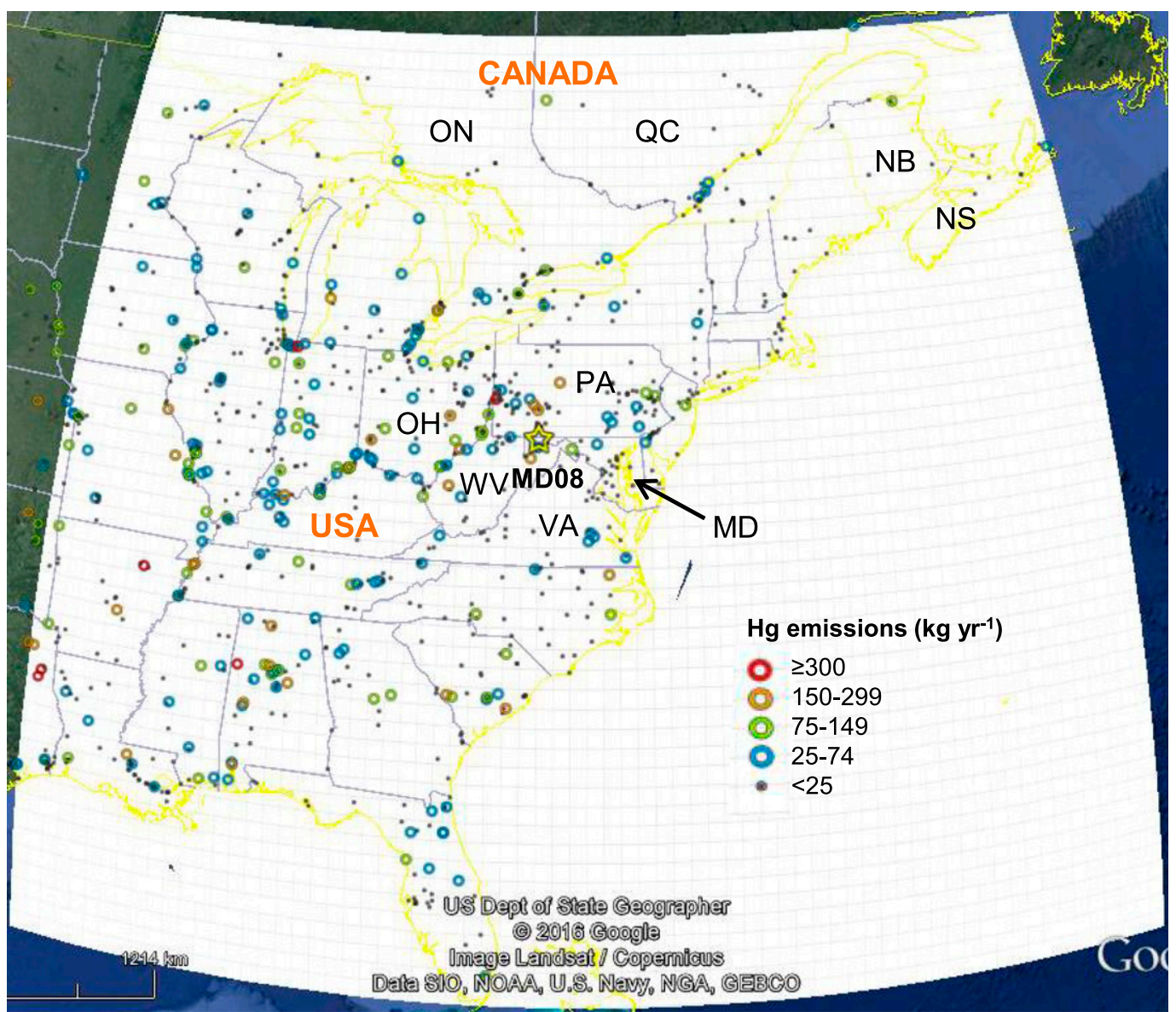

FIG. 1. Geographical domain covering southeastern Canada and eastern United States. Mercury point-source locations and emissions in 2014 from the National Pollutant Release Inventory (NPRI; Environment and Climate Change Canada 2016a) and Toxics Release Inventory (TRI; EPA 2016). MD08: Piney Creek Reservoir sampling site; MD: Maryland; NB: New Brunswick; NS: Nova Scotia; OH: Ohio; ON: Ontario; PA: Pennsylvania; QC: Quebec; VA: Virginia; WV: West Virginia.

corresponding to a back-trajectory $l$ initiated at MD08. Because of the potential measurement uncertainties in GOM and PBM, the sum of the two oxidized $\mathrm{Hg}$ forms (RM) was also used in the $P_{i j}$ calculations. The term $\tau_{i j l}$ is the residence time of a back trajectory over a particular grid cell. This is determined by counting the number of hourly trajectory segment endpoints traveling over each grid cell for each trajectory $l$ and then dividing by the total number of hourly trajectory segment endpoints for $l$. This computation was done for all trajectories $L$ over a specific time period. Although wind field errors can lead to large deviations in the trajectory path, the $P_{i j}$ distributions are accumulated over thousands of trajectory simulations in the CWT method, which have less uncertainties compared to running a small number of trajectory simulations.

Back trajectories were generated using the HYSPLIT 4 model (Rolph 2017; Stein et al. 2015). A trajectory duration of $72 \mathrm{~h}$ and the EDAS $40-\mathrm{km}$ archived meteorological data were selected. Back trajectories were initiated every $3 \mathrm{~h}$ corresponding to the sampling and desorption/analysis period of the GOM and PBM measurements. Five-minute GEM measurements were bihourly averaged corresponding to the sampling period of GOM and PBM. One half of the modeled mixedlayer height was selected as the starting height. Aside from the trajectory segment endpoints, the modeled mixed-layer heights along the trajectory were also included in the output. Note that only the trajectory segment endpoints located within the modeled mixed-layer height were counted (Ren et al. 2016). This ensured only the emission sources within the planetary boundary layer (PBL) were considered, and potential transport from the free troposphere that may be attributed to long-range transport of emissions was excluded. However, a fraction of the anthropogenic $\mathrm{Hg}$ emissions 
may be omitted in cases where tall stacks inject flue gases above the PBL or when there is a shallow nocturnal boundary layer. Once injected above the PBL, the $\mathrm{Hg}$ emissions could influence downwind regions and affect the surface during subsidence/downward mixing. The geographical domain consists of 3500 grid cells that cover the eastern United States and southeastern Canada (Fig. $1 ; 25^{\circ}-50^{\circ} \mathrm{N}, 60^{\circ}-95^{\circ} \mathrm{W}$ ).

\section{Results and discussion}

\section{a. Trends in modeled source regions and Hg point-source emissions}

The source strengths $P_{i j}$ above the 50th and above the 75 th percentiles from all years were selected as the thresholds to determine the number of major source regions or hotspots in the eastern United States and southeastern Canada contributing to $\mathrm{Hg}$ concentrations at MD08 over three time periods: 2006-08, 2009-11, and 2013-2014. Different thresholds were analyzed to assess the effects on the trends in the number of source regions. Table 1 shows a clear decline in the number of major source regions contributing to GEM, GOM, and RM over the three periods. The results were consistent for the 50th- and 75th-percentile CWT thresholds. Similarly, the average source intensities predicted by the CWT method for GEM, GOM, and RM also declined over the three periods (Table 1). These results are likely attributable to $\mathrm{Hg}$ emissions reductions from power plants and non-power-plant sources (Table 1). In contrast, the number of major source regions impacting PBM declined from 2006-08 to 2009-11, but then increased in 2013-14. Note that these results only capture the fraction of mercury on particles $<2.5 \mu \mathrm{m}$. The increase in the number of hotspots for $\operatorname{PBM}(<2.5 \mu \mathrm{m})$ is likely not attributable to $\mathrm{Hg}$ point-source emissions because less than $5 \%$ of the total $\mathrm{Hg}$ emissions from combustion and industrial sources are PBM (Zhang et al. 2016a). PBM can be emitted from soil/dust resuspension and wood combustion and could also be formed via heterogeneous chemistry and gas-particle partitioning.

The number of major source regions for GEM, GOM, and RM also declined over time in each season (Fig. S2 of the supplemental material). During the winter, spring, and summer, the largest decrease in the number of GEM hotspots occurred between the 2006-08 and 2009-11 periods. In contrast, only a minor decrease was observed over the three periods during fall. The larger decreases in the winter, spring, and summer are potentially due to the higher coal consumption for power generation during these seasons for winter heating and summer air conditioning (Energy Information Administration 2017). Thus $\mathrm{Hg}$ emissions reductions from power plants had greater impacts on the number of GEM hotspots during these seasons compared to fall. The number of major source regions for GOM decreased over time in each season, which is mainly attributable to $\mathrm{Hg}$ emissions reductions. A greater decline in the number of major source regions in GOM from 2009-11 to 2013-14 during summer was partially due to higher wet deposition in the summer (attributed to higher rainfall; NOAA 2017), resulting in lower GOM concentrations and subsequently lower source intensities for GOM. This was also reflected in the PBM results, which had a lower number of major source regions in the summers of 2013-14 instead of the increases observed in other seasons. Similar to GOM, this is potentially attributable to greater wet scavenging of PBM during summer, leading to lower PBM concentrations and subsequently lower source intensities of PBM.

\section{b. Comparison between two time periods: 2006-08 versus 2011, 2013-14 \\ 1) Change in PRedicted source CONTRIBUTIONS OF GEM, GOM, PBM, AND RM}

The modeled source contributions generated from the CWT method were compared between two time periods: $2006-08$ refers to the period before $\mathrm{Hg}$ pollution control policies (e.g., CAIR and MATS) were introduced, whereas 2011, 2013-14 covers the period when the policies came into effect. In the latter period, total $\mathrm{Hg}$ point-source emissions across southeastern Canada and the eastern United States decreased by 39\% compared to 2006-08. The source contributions of GEM over most of southeastern Canada and the eastern United States decreased by up to $20 \%$ from 2006-08 to 2011, 2013-14 in the majority of the areas (Fig. 2). In some parts of New Jersey, North Carolina, South Carolina, and Georgia, larger decreases in the CWT for GEM were found $(20 \%-60 \%)$. For GOM, the predicted source contributions declined significantly from 2006-08 to $2011,2013-14$ (by $>60 \%$ ) throughout much of the eastern United States (Fig. 2). This was observed in regions upwind of MD08, including the northwest through southwest wind directions (Pennsylvania, Ohio, and West Virginia) and east through southeast wind directions (eastern Maryland and Virginia). Modeled source intensities of PBM $(<2.5 \mu \mathrm{m})$ decreased by $20 \%-60 \%$ regionally and $<20 \%$ in the vicinity of MD08 in 2011, 2013-14 (Fig. 2). PBM source intensities declined substantially by $>60 \%$ in southern Quebec and in central New York. For RM (GOM+PBM), the modeled 
TABLE 1. Number of $\mathrm{Hg}$ source regions predicted by CWT method and $\mathrm{Hg}$ point-source emissions and power-plant $\mathrm{Hg}$ emissions over three time periods.

\begin{tabular}{|c|c|c|c|}
\hline & $2006-08$ & $2009-11$ & 2013-14 \\
\hline \multicolumn{4}{|c|}{ Number of $\mathrm{Hg}$ source regions } \\
\hline \multicolumn{4}{|c|}{$P_{i j} \geq 75$ th percentile $^{\mathrm{a}}$} \\
\hline GEM & 1840 & 369 & 317 \\
\hline GOM & 1865 & 538 & 223 \\
\hline PBM & 1100 & 493 & 1035 \\
\hline $\mathrm{RM}$ & 1768 & 532 & 325 \\
\hline \multicolumn{4}{|l|}{$P_{i j} \geq 50$ th percentile pe $^{\mathrm{b}}$} \\
\hline GEM & 2397 & 1655 & 1286 \\
\hline GOM & 2306 & 1818 & 1126 \\
\hline PBM & 1909 & 1547 & 1792 \\
\hline $\mathrm{RM}$ & 2212 & 1543 & 1495 \\
\hline \multicolumn{4}{|c|}{ Average source intensity $\left(P_{i j}\right)$} \\
\hline GEM & 1.50 & 1.35 & 1.32 \\
\hline GOM & 13.93 & 6.88 & 5.05 \\
\hline PBM & 4.50 & 3.29 & 4.46 \\
\hline $\mathrm{RM}$ & 17.95 & 9.86 & 9.56 \\
\hline \multicolumn{4}{|c|}{ Emissions $^{c}$} \\
\hline $\begin{array}{l}\text { Total Hg point-source } \\
\text { emissions }\left(\mathrm{kg} \mathrm{yr}^{-1}\right)\end{array}$ & 40677 & 29670 & 23987 \\
\hline $\begin{array}{l}\text { Power-plant } \mathrm{Hg} \\
\text { emissions }\left(\mathrm{kg} \mathrm{yr}^{-1}\right)\end{array}$ & 30150 & 19107 & 12904 \\
\hline \multicolumn{4}{|c|}{$\begin{array}{l}{ }^{\mathrm{a}} \text { The } 75 \text { th percentile } P_{i j} \text { thresholds are GEM } 1.44 \text {, GOM 9.4, PBM } \\
\text { 4.85, RM } 13.54 \text {. } \\
\text { b The 50th percentile } P_{i j} \text { thresholds are GEM 1.34, GOM 4.5, PBM } \\
2.83, \text { RM 8.14. }\end{array}$} \\
\hline \multicolumn{4}{|c|}{$\begin{array}{l}{ }^{c} \text { Emissions over southeastern Canada and eastern United States } \\
\text { only. Data from NPRI (Environment and Climate Change } \\
\text { Canada 2016a) and TRI (EPA 2016). }\end{array}$} \\
\hline
\end{tabular}

source contributions to MD08 decreased moderately $(20 \%-60 \%)$ in the Midwest and mid-Atlantic regions of the United States (Fig. 2). Some localized areas in the prevailing wind direction of MD08 experienced declines in the source contributions to RM exceeding $60 \%$ (e.g., west of MD08 in Ohio and east of MD08 in Pennsylvania).

There were several regions where the source contributions increased in 2011, 2013-14. For GEM, predicted source contributions increased slightly (up to $20 \%$ ) in central Ontario, southern Quebec, the northeastern United States, the mid-Atlantic Ocean, and the southern United States. For GOM, the source contributions increased in southern Quebec, the northeastern United States, and the Atlantic Ocean off the coast of Florida. Increases in the modeled source contributions of PBM in 2011, 2013-14 were more widespread. It included parts of central Ontario, southern Quebec, the northeastern United States, the mid-Atlantic Ocean, and the southern and central United States. The increases in the source strengths in central Ontario and southern Quebec may be due to the increase in the number of forest fires (Canadian Forest Service 2017) from 200608 to 2011, 2013-14, which ranged from an increase from 1 fire to 50 fires depending on the grid cell (Fig. S3). The results were further compared with the geographical distributions of the fire radiative power (FRP) from MODIS (NASA 2017), which measures the amount of power released by fires, over the entire model domain. Figure S4 in the supplemental material illustrates the geographical distributions of the source intensities of PBM and FRP for the 2006-08 and 2011, 2013-14 periods during MaySeptember, which is the period when wildfires typically occur. The discrepancies in the spatial distributions suggest that the higher source intensities of PBM during May-September were not attributed to wildfire events. Higher PBM source intensities were found at higher latitudes, such as the upper U.S. Midwest and southern Ontario and Quebec. In contrast, stronger FRP were observed at lower latitudes in the southern and southeastern United States. The source intensities of PBM were lower over the higher-latitude regions and higher over southeastern United States in 2011, 2013-14 compared to 2006-08; however, the spatial distributions of the FRP were relatively the same during the two periods.

\section{2) Change in total Hg emissions AND POWER-PLANT HG EMISSIONS}

Figure S5a in the supplemental material shows that the total $\mathrm{Hg}$ air emissions [U.S. Environmental Protection Agency (EPA) 2016] have declined over much of the eastern United States in 2011, 2013-14. Near MD08, the decline in total $\mathrm{Hg}$ emissions ranged from $20 \%$ to $60 \%$ and may even exceed $60 \%$ (Fig. S5b). In terms of absolute changes, this translates to $\mathrm{Hg}$ emission decreases of 50-200 kg and exceeding $300 \mathrm{~kg}$ in a few areas (Figs. S6a,b). The largest emissions decrease in 2011, 2013-14 can be found just east of MD08 and in regions farther away to the southeast (eastern Maryland) and southwest (West Virginia) of MD08, which are consistent with the decrease in predicted source intensities of GEM. Much of the decline in total $\mathrm{Hg}$ air emissions in the eastern United States in 2011, 2013-14 can be attributed to decreases in $\mathrm{Hg}$ emissions from power plants (Fig. S5c). The map of gridded $\mathrm{Hg}$ emissions from power plants indicate significant decreases $(>60 \%)$ close to MD08, along the East Coast of the United States, and the southeastern United States in 2011, 2013-14 (Fig. S5d). The magnitude of the $\mathrm{Hg}$ emissions reductions from power plants near MD08 ranged from as low as $5 \mathrm{~kg}$ to above $300 \mathrm{~kg}$ (Fig. S6d). The areas near MD08 that experienced large declines in $\mathrm{Hg}$ emissions from power plants are upwind of MD08 (northwest through southwest and east through southeast wind directions) and are consistent with the large declines in 

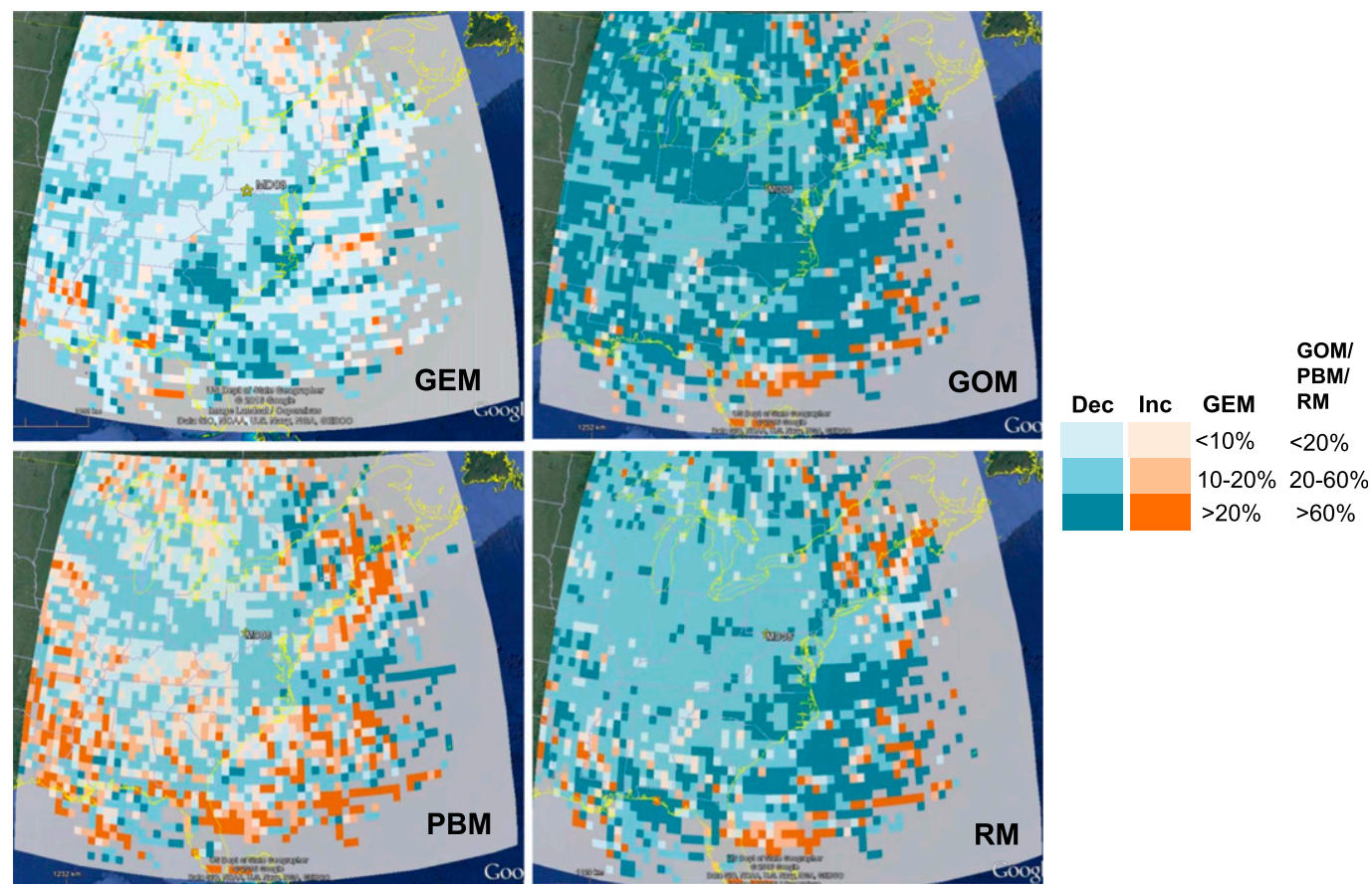

FIG. 2. Percentage change in source intensities predicted by CWT method between 2006-08 and 2011, 2013-14.

Dec: decrease; Inc: increase.

GOM and PBM source intensities. Thus, the CWT method confirmed the strong effects of power-plant $\mathrm{Hg}$ emissions on speciated atmospheric $\mathrm{Hg}$ concentrations at MD08, suggesting that policies aimed at curbing $\mathrm{Hg}$ emissions from power plants have been effective.

Note that the reductions in power-plant $\mathrm{Hg}$ emissions resulted in a much larger percentage decline in the source contributions of GOM than PBM and GEM. This is likely because GOM constitutes a larger fraction of the total $\mathrm{Hg}$ emissions from power plants than PBM (Zhang et al. 2016a). The percentage declines in the source contributions from 2006-08 to 2011, 2013-14 in GEM were lower than GOM. It is possible that the air pollution control devices implemented in power plants were more effective at removing GOM than PBM or GEM. For example, the use of wet flue gas desulfurization to remove $\mathrm{SO}_{2}$ in flue gas is also effective in removing GOM because GOM is water soluble and has a tendency to adhere to surfaces (Zhang et al. 2016a,c).

The increases in source intensities over time in central Ontario, southern Quebec, and the northeastern United States are not attributed to increases in power-plant $\mathrm{Hg}$ emissions. As shown in Fig. S5c, there were very few increases in power-plant $\mathrm{Hg}$ emissions in central Ontario, southern Quebec, and the U.S. Northeast. However, the total $\mathrm{Hg}$ emissions map (Fig. S5a) indicate some areas in central Ontario, southern Quebec, and the U.S. Northeast with significant increases $(>60 \%)$. This suggests that $\mathrm{Hg}$ emissions from other sources besides power plants have increased in 2011, 2013-14 over these areas. Emissions inventories in Canada (Environment and Climate Change Canada 2016a) and the United States (EPA 2016) indicate the increase in $\mathrm{Hg}$ emissions in 2011, 2013-14 were predominantly from steel and metal production. As shown in Table S1, the top five sources of mercury emissions in southeastern Canada were iron and steel production, other metal production, nonmetallic mineral production (e.g., cement), power plants, and water and wastewater systems. In the eastern United States, the top five sources of mercury emissions were the power-plant, primary metal, nonmetallic mineral (e.g., cement), paper, and petroleum industries. These top five mercury point sources comprised more than $90 \%$ of the anthropogenic mercury emissions. Over central Ontario, southern Quebec, and the U.S. Northeast in particular, there were more metal, nonmetallic mineral, and paper industries than power plants (Fig. S1), which may further explain the increase in predicted source intensities in these regions.

3) Change in surface TEMPeratures, GEM CONCENTRATIONS, AND SOIL EMISSION POTENTIAL

Figure $\mathrm{S} 7$ shows the percentage change in temperature from 2006-08 to 2011, 2013-14 in five of the U.S. climate regions that make up the eastern United States 
and in the southeastern provinces of Canada. Although surface temperature trends have been increasing in Canada since the 1950s and in the United States since 1985 (Vincent et al. 2015; NOAA 2017), short-term declines in the annual-average surface temperatures were observed from 2006-08 to 2011, 2013-14 (Environment and Climate Change Canada 2012, 2016b; NOAA 2017). The decrease in surface temperatures was not spatially uniform over southeastern Canada and the eastern United States. The largest percentage decrease was observed in central and southern Ontario $(-17.5 \%)$, followed by the upper Midwest in the United States $(-15.1 \%)$, southern Quebec $(-10.7 \%)$, New Brunswick $(-9.5 \%)$, the Ohio River valley $(-5.6 \%)$, the northeastern United States $(-3.2 \%)$, the southeastern United States $(-2.0 \%)$, the southern United States $(-1.8 \%)$, and Nova Scotia $(-1.1 \%)$. Figure S7 illustrates that the U.S. regions with larger temperature declines (the upper Midwest, Ohio River valley) had few increases in the predicted source intensities likely because of less natural emissions or reemissions of GEM. In contrast, the regions with slight temperature declines (Northeast, Southeast, and South) had a higher number of areas with increases in the predicted source intensities. Although temperature declines from 2006-08 to 2011, 2013-14 were quite large in central and southern Ontario and southern Quebec, an increase in the predicted source contributions of GEM were observed in many areas. Thus, temperature-driven emissions of GEM do not fully account for the change in the source intensities of GEM over time.

The nonuniform temperature decreases could play a role in the spatial variability of the predicted source intensities of PBM because temperature can affect gas-particle partitioning. Although in theory the partitioning of oxidized $\mathrm{Hg}$ to particles should be greater with larger temperature declines, this was not clearly reflected in the predicted source contributions. In the United States, the decrease in the PBM source contributions occurred in regions with larger temperature declines from 2006-08 to 2011, 2013-14, and vice versa (Fig. S8). However, in Canada, the increase in the PBM source intensities was consistent with the large temperature declines mainly in central and southern Ontario and southern Quebec. It is likely that the higher average temperatures in eastern United States led to less partitioning of GOM to PBM, while the lower average temperatures in southeastern Canada resulted in more gas-particle partitioning. In 2011, 2013-14, the average temperatures across the five U.S. climate regions ranged from $6.0^{\circ}$ to $17.2^{\circ} \mathrm{C}$, whereas the average temperatures in southeastern Canada ranged from $4.2^{\circ}$ to $7.1^{\circ} \mathrm{C}$.
It should be noted that ambient GEM concentrations, soil emission potential, soil moisture, and solar radiation are other important factors besides temperature that affect GEM emission from surfaces. Lower ambient air GEM could increase plant and soil GEM emissions because of a larger flux gradient from the surface to the atmosphere as estimated from dry deposition models (Zhang et al. 2016b) and laboratory flux measurements (Hanson et al. 1995). Although annual-average GEM concentrations from 2009 to 2014 decreased slightly, there was a large decrease in the number of short-term high-concentration events $\left(>1.7 \mathrm{ng} \mathrm{m}^{-3}\right.$, $>90$ th percentile) during this period. Zhang et al. (2016b) estimated annual natural and reemissions of GEM at MD08 to be $16.4-20.3 \mu \mathrm{g} \mathrm{m}^{-2}$ during the 6-yr period from 2009 to 2014. Such large interannual variations in GEM natural emissions are potentially influenced by decreasing ambient GEM concentrations and/or number of highconcentration events considering the very small interannual variations in temperature.

\section{c. Change in spatial distribution of source regions over time}

\section{1) GEM}

At MD08, the source regions of GEM that were located in eastern Maryland and Pennsylvania and in New Jersey during the 2006-08 period (Fig. 3a) were no longer present during 2013-14 (Fig. 3c). This is likely attributable to $\mathrm{Hg}$ emissions reductions, as shown in Figs. 3a and 3c (i.e., conversion from green to gray circles in eastern Maryland and Pennsylvania and in New Jersey). There were also source regions near the border of central Ontario and Quebec that were present during 2009-11 but were absent during 2006-08. This may be attributed to increased forest fires in this region during 2009-11 (Fig. S9). The results were also compared to a study conducted at the Beltsville site ( $\sim 200 \mathrm{~km}$ southeast of MD08) in eastern Maryland, which applied a similar trajectory-based method (Ren et al. 2016). The modeled sources impacting MD08 (Fig. 3a) and Beltsville during 2006-08 were predominantly from the direction west of the sites. The regions with the least influence on GEM at MD08 and Beltsville were both in the northeastern United States and southern Ontario. These similarities are also apparent in the 2009-11 and 2013-14 maps (Figs. 3b,c). Similar to the results in this study, the source regions that were contributing to GEM in Beltsville during 2007-09 (located in eastern Pennsylvania and in New Jersey, northeast of Beltsville) were not discernable during 2013-14.

The discrepancy in the predicted source regions of GEM at MD08 and Beltsville can be attributed to the 

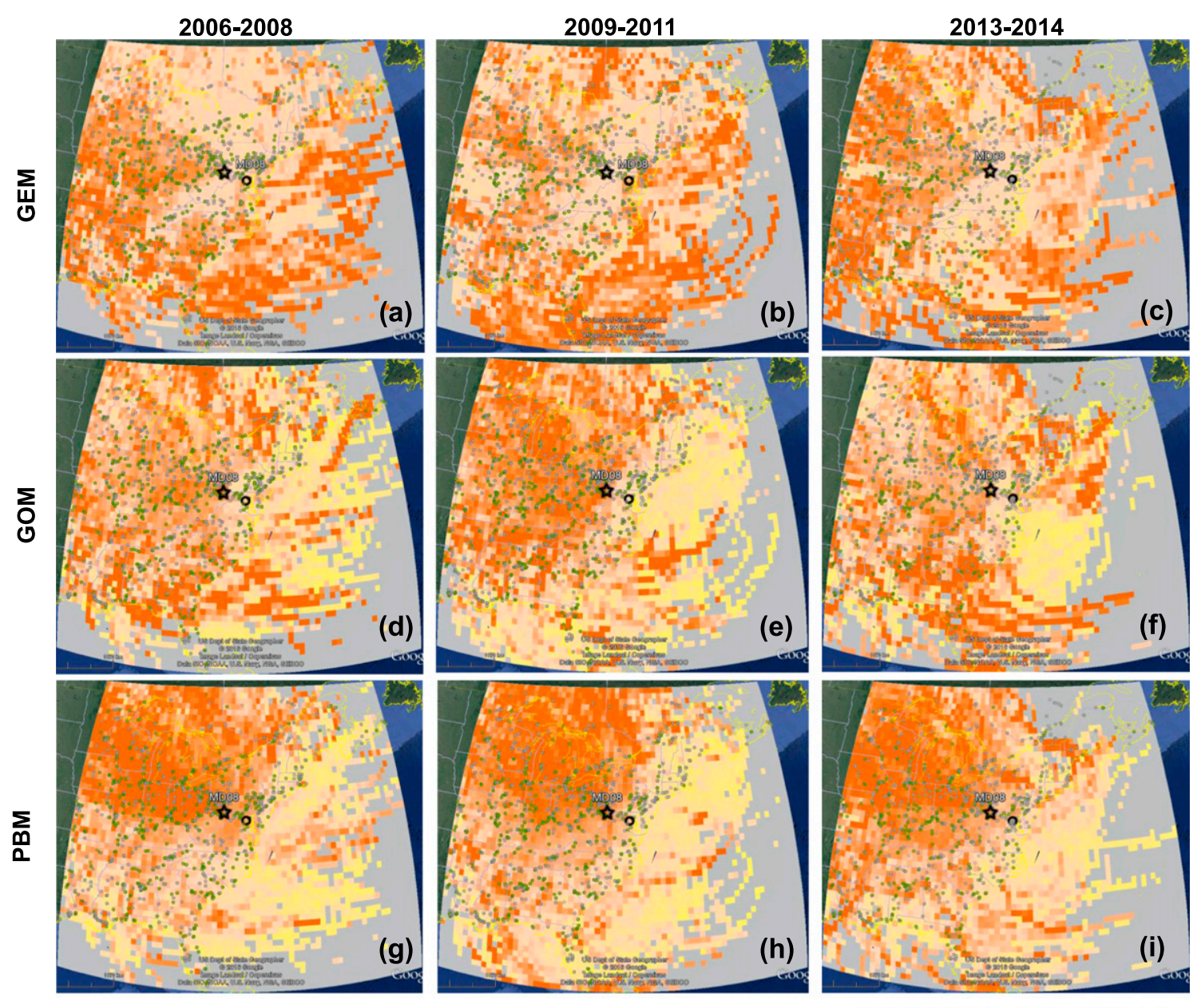

Weak source

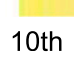

50th 90th

FIG. 3. Spatial distribution of predicted source regions over time; 10 th, 50th, and 90th refer to $P_{i j}$ [Eq. (1)] percentiles. Star: MD08; black

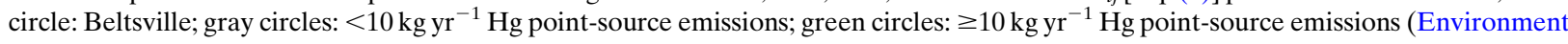
and Climate Change Canada 2016a; EPA 2016).

different locations and wind fields and differences in the receptor methods. For example, Virginia was a significant source of GEM to Beltsville (Ren et al. 2016) but had almost no influence on MD08 during all three periods. This discrepancy may be due to the fact that Beltsville is southeast of MD08. The prevailing wind direction at both sites is from the west, which likely explains why sources in Virginia were contributing to Beltsville but not MD08. Another discrepancy was that the southeastern Canada and northeastern U.S. regions were not considered sources of GEM to Beltsville despite the presence of $\mathrm{Hg}$ point sources and forest fires (Figs. 3 and S9). However, in this study, some localized areas within this region were identified as potential strong (dark orange) to medium (orange) sources that impacted MD08 during 2006-08. The difference in these results is likely attributable to different source apportionment methods. The CWT method utilizes all the concentrations and the corresponding trajectory residence times to calculate the source contributions; however, only the trajectory frequencies associated with the highest ( $\geq 90$ th percentile) and lowest ( $\leq 10$ th percentile) concentrations were considered by Ren et al. (2016). Thus, the CWT method was able to identify large $\mathrm{Hg}$ point sources ( $\geq 10 \mathrm{~kg}$; green) as well as moderate to small $\mathrm{Hg}$ point sources $(<10 \mathrm{~kg}$; gray). The method used in Ren et al. (2016) captured mainly the large $\mathrm{Hg}$ point sources that are concentrated in the Midwest and Pennsylvania because of the higher concentration thresholds used to define source regions. Furthermore, the higher proportion of smaller $\mathrm{Hg}$ point sources in the southeastern Canada and northeastern U.S. regions also led to some large $\mathrm{Hg}$ point sources (e.g., in Connecticut, Massachusetts, southern Quebec, Nova Scotia) being 
omitted by Ren et al. (2016) during the first and second time periods. These results suggest that the CWT method can accurately locate large and small $\mathrm{Hg}$ point sources that are not necessarily clustered together over a large region.

\section{2) $\mathrm{GOM}$}

The major source regions contributing GOM to MD08 during 2006-08 are concentrated in the southeastern United States, central Ontario, and Nova Scotia and along the southern Ontario-Quebec corridor (Fig. 3d). By 2009-11, many of the source regions in the southeastern United States and Nova Scotia had converted to weak source regions (Fig. 3e). The major source regions during 2009-11 were found predominantly in the region west of MD08, where the majority of $\mathrm{Hg}$ point sources are located. From 2009-11 to 2013-14, the source regions west of MD08 transitioned to weaker source regions, which are consistent with the significant reductions in $\mathrm{Hg}$ emissions (Fig. 3f). There were also decreases in the predicted source intensities in central Ontario and along the southern OntarioQuebec corridor in 2013-14 that appears to be in line with decreasing $\mathrm{Hg}$ emissions in southeastern Canada (Fig. 3f) and also declines in the number of forest fires (Fig. S9).

The map of source contributions of GOM for MD08 was mostly consistent with that of Beltsville, although there were some discrepancies. In both maps of the predicted source regions during the 2007-14 period (Fig. S10a), the clean regions were located along the eastern U.S. coastline. The major source regions of GOM for MD08 and Beltsville were west of these clean regions. There were some differences in the maps of the source regions for GOM as well. The southern Quebec region, Nova Scotia, coastal areas of Alabama and Florida, and mid-Atlantic Ocean region were identified as potential sources impacting GOM at MD08 but not Beltsville. GOM concentrations in the subtropical North Atlantic Ocean can range from 2.5 to $40 \mathrm{pg} \mathrm{m}^{-3}$ (Laurier and Mason 2007; Sillman et al. 2007; Soerensen et al. 2010; Ren et al. 2014). One potential source of GOM over the subtropical Atlantic Ocean is the photochemical oxidation of GEM (Laurier and Mason 2007; Sillman et al. 2007; Ren et al. 2014). This was identified by the presence of a strong diurnal variation in GOM, with concentrations increasing during daytime and peaking to a maximum in the afternoon and then decreasing to a minimum at night. The diurnal cycle of GOM was consistent with the variation in solar radiation and inversely related to ozone; the latter suggests the presence of reactive halogen species produced from sea salt particles reacted with ozone and simultaneously oxidized GEM (Laurier and Mason 2007). Continental outflow is also a potential source of GOM in the Atlantic Ocean due to land-sea breeze circulation patterns affecting coastal areas (Lan et al. 2014). At a coastal site around the Mississippi-Alabama border, high GOM concentrations were attributed to GEM oxidation because of the presence of elevated ozone and solar radiation. Another source of GOM in this particular region was from direct emissions from a local power plant and petroleum refinery (Ren et al. 2014). The discrepancy between MD08 and Beltsville is potentially related to the differences in the receptor methods as discussed earlier. The CWT method appears to have a greater capability in resolving moderate $\mathrm{Hg}$ emissions source regions.

\section{3) PBM}

The predicted source regions of $\mathrm{PBM}(<2.5 \mu \mathrm{m})$ during the three time periods were mainly found in the region northwest of MD08, including the midwestern United States, central and southern Ontario, and southern Quebec. This is likely because of a combination of factors related to the higher latitudes of these regions, such as longer winter periods, which lead to an increase in fossil fuel and wood combustion emissions in these regions, and the tendency for gas-particle partitioning at lower temperatures. The midwestern United States is also a source of fine particulate matter as a result of the agricultural activity. The size of the predicted source region has decreased over time. During the 2006-08 and 2009-11 periods, the major source regions of PBM included much of Indiana and Ohio (Figs. 3g,h). By 2013-14, the major source regions receded to one-half the area of Indiana and Ohio (Fig. 3i). This is partly due to a decrease in $\mathrm{Hg}$ emissions in Ohio and West Virginia. In contrast, the southeastern United States and the East Coast had minor impacts on PBM at MD08. The southeastern United States, because of its lower latitude, does not experience prolonged periods of cold temperatures. Thus, there is likely less combustion emissions and gas-particle partitioning in that region during winter compared to northern latitudes. The U.S. East Coast is frequently impacted by cleaner marine airflows from the Atlantic Ocean, which is considered a negligible source of PBM $(<2.5 \mu \mathrm{m})$ because of a lack of anthropogenic and ground emissions. The source regions contributing PBM to MD08 (Fig. S10b) and Beltsville (Ren et al. 2016) over the 2007-14 period were mostly consistent between the sites. Both studies predicted the source regions are located northwest of the sites, covering the northern and midwestern United States and central Ontario. Overall the spatial distribution of the predicted source regions of GEM, GOM, 
and PBM impacting Piney Creek Reservoir were comparable to that impacting Beltsville (Ren et al. 2016), suggesting source apportionment methods that integrate back trajectories and receptor air concentrations are capable of producing consistent results at two midAtlantic locations. However, some parts of southern Quebec also affected PBM at MD08. Potential sources in southern Quebec included mercury point sources and forest fire emissions (Figs. S9 and S10b). These results were not identified at Beltsville because of differences in the methods for predicting source regions as discussed earlier.

\section{Conclusions}

The source regions contributing to atmospheric $\mathrm{Hg}$ measured at Piney Creek Reservoir, Maryland (MD08), were predicted using the CWT method for the periods before (2006-08) and after $(2011,2013-14)$ the introduction of mercury emission reductions from U.S. power plants. The CWT method predicted that the number of major source regions declined, and source contributions of GEM, GOM, and RM over much of southeastern Canada and eastern United States also decreased over time, driven primarily by reductions in $\mathrm{Hg}$ emissions from power plants in the United States. The mercury emission reduction policies were particularly effective in reducing the source contributions of GOM in the vicinity of MD08 compared to PBM or GEM. The smaller percentage decreases in PBM than in GOM were likely because GOM constitutes a larger fraction of the total $\mathrm{Hg}$ emissions from power plants than PBM. The smaller percentage decreases in GEM than in GOM (and in some areas even increases in GEM) were likely due to the increased emissions from non-power-plant sources and forest fires as well as potential increases in natural emissions and reemissions of predeposited mercury. Future studies should provide more accurate natural/reemission estimates under the scenario of decreasing ambient GEM, increasing temperature, and likely decreasing soil emission potential (assuming wet and dry deposition are decreasing) in order to fully understand the temporal variations of the speciated mercury. While this study focused on assessing the effectiveness of policies targeting mercury emissions from power plants, future work could examine the change in the impact of other emission sectors that are under the Minamata Convention on mercury. Unprecedented increases in global surface temperatures over the recent decades also warrant further studies on the role of surface temperatures on mercury emissions from land and ocean surfaces and forest fire emissions.
Acknowledgments. The collection of the mercury data was supported by grants from the Maryland Department of Natural Resources and U.S. EPA's Clean Air Markets Program. This publication is assigned the University of Maryland Center for Environmental Science Contribution Number 5374. Funding for the publication was provided by the Climate Change and Air Pollution Program of Environment and Climate Change Canada (ECCC). We gratefully acknowledge the National Atmospheric Deposition Program's Atmospheric Mercury Network, ECCC's National Pollutant Release Inventory and U.S. EPA's Toxics Release Inventory, climate data trends from ECCC's Climate Research Division and NOAA's National Centers for Environmental Information, and Canadian Forest Service of the Natural Resources of Canada for the datasets used in this publication; NOAA Air Resources Laboratory (ARL) for the provision of the HYSPLIT transport and dispersion model and/or READY website (http://www.ready.noaa.gov), and use of data and imagery from LANCE FIRMS operated by the NASA/GSFC/ Earth Science Data and Information System (ESDIS) with funding provided by NASA/HQ. We thank Kenjiro Toyota and Amanda Cole from ECCC for helpful comments.

\section{REFERENCES}

Canadian Forest Service, 2017: National Fire Database-Agency fire data. Natural Resources Canada, accessed 10 February 2017. [Available online at http://cwfis.cfs.nrcan.gc.ca/datamart.]

Castro, M. S., and J. Sherwell, 2015: Effectiveness of emission controls to reduce the atmospheric concentrations of mercury. Environ. Sci. Technol., 49, 14000-14007, doi:10.1021/acs. est.5b03576.

Cheng, I., L. Zhang, P. Blanchard, J. Dalziel, and R. Tordon, 2013: Concentration-weighted trajectory approach to identifying potential sources of speciated atmospheric mercury at an urban coastal site in Nova Scotia, Canada. Atmos. Chem. Phys., 13, 6031-6048, doi:10.5194/acp-13-6031-2013.

_, X. Xu, and L. Zhang, 2015: Overview of receptor-based source apportionment studies for speciated atmospheric mercury. Atmos. Chem. Phys., 15, 7877-7895, doi:10.5194/ acp-15-7877-2015.

Energy Information Administration, 2017: Electric power monthly. Independent Statistics \& Analysis, U.S. Department of Energy, accessed 2 March 2017. [Available online at http:// www.eia.gov/electricity/monthly/epm_table_grapher.cfm? $\mathrm{t}=$ epmt_2_01_a.]

Environment and Climate Change Canada, 2012: Monthly mean of daily mean temperature. Homogenized surface air temperature data access, accessed 9 February 2017. [Available online at ftp://ccrp.tor.ec.gc.ca/pub/AHCCD/Homog_monthly_mean_ temp.zip.]

_ 2016a: Bulk data (1993 to present). National Pollutant Release Inventory (NPRI) datasets, accessed 7 November 2016. [Available online at http://open.canada.ca/data/en/dataset/ 40e01423-7728-429c-ac9d-2954385ccdfb.]

_, 2016b: Climate trends and variations bulletin-Annual 2015. Accessed 27 February 2017, 4 pp. [Available online at 
http://publications.gc.ca/collections/collection_2016/eccc/En8123-2015-eng.pdf.]

EPA, 2016: Toxics Release Inventory (TRI). TRI Explorer, accessed 7 November 2016. [Available online at https:// iaspub.epa.gov/triexplorer/tri_release.facility.]

Fu, X. W., X. Feng, P. Liang, H. Zhang, J. Ji, and P. Liu, 2012: Temporal trend and sources of speciated atmospheric mercury at Waliguan GAW station, northwestern China. Atmos. Chem. Phys., 12, 1951-1964, doi:10.5194/acp-12-1951-2012.

Gay, D. A., D. Schmeltz, E. Prestbo, M. Olson, T. Sharac, and R. Tordon, 2013: The Atmospheric Mercury Network: Measurement and initial examination of an ongoing atmospheric mercury record across North America. Atmos. Chem. Phys., 13, 11339-11349, doi:10.5194/acp-13-11339-2013.

Giang, A., L. C. Stokes, D. G. Streets, E. S. Corbitt, and N. E. Selin, 2015: Impacts of the Minamata Convention on mercury emissions and global deposition from coal-fired power generation in Asia. Environ. Sci. Technol., 49, 5326-5335, doi:10.1021/acs.est.5b00074.

Han, Y. J., T. M. Holsen, and P. K. Hopke, 2007: Estimation of source locations of total gaseous mercury measured in New York State using trajectory-based models. Atmos. Environ., 41, 6033-6047, doi:10.1016/j.atmosenv.2007.03.027.

Hanson, P. J., S. E. Lindberg, T. A. Tabberer, J. A. Owens, and K. H. Kim, 1995: Foliar exchange of mercury vapor: Evidence for a compensation point. Water Air Soil Pollut., 80, 373-382, doi:10.1007/BF01189687.

Hopke, P. K., 2016: Review of receptor modeling methods for source apportionment. J. Air Waste Manage. Assoc., 66, 237-259, doi:10.1080/10962247.2016.1140693.

Jeong, U., J. Kim, H. Lee, J. Jung, Y. J. Kim, C. H. Song, and J.-H. Koo, 2011: Estimation of the contributions of long range transported aerosol in East Asia to carbonaceous aerosol and PM concentrations in Seoul, Korea using highly time resolved measurements: A PSCF model approach. J. Environ. Monit., 13, 1905-1918, doi:10.1039/c0em00659a.

Kabashnikov, V. P., A. P. Chaikovsky, T. L. Kucsera, and N. S. Metelskaya, 2011: Estimated accuracy of three common trajectory statistical methods. Atmos. Environ., 45, 5425-5430, doi:10.1016/j.atmosenv.2011.07.006.

Lan, X., R. Talbot, P. Laine, B. Lefer, J. Flynn, and A. Torres, 2014: Seasonal and diurnal variations of total gaseous mercury in urban Houston, TX, USA. Atmosphere, 5, 399-419, doi:10.3390/atmos5020399.

Laurier, F., and R. Mason, 2007: Mercury concentration and speciation in the coastal and open ocean boundary layer. J. Geophys. Res., 112, D06302, doi:10.1029/2006JD007320.

Lee, G. S., P. R. Kim, Y. J. Han, T. M. Holsen, and S. H. Lee, 2014: Tracing sources of total gaseous mercury to Yongheung Island off the coast of Korea. Atmosphere, 5, 273-291, doi:10.3390/ atmos5020273.

NASA, 2017: MODIS/Aqua+Terra Thermal Anomalies/Fire locations 1km FIRMS V006 NRT. Accessed 26 April 2017, doi:10.5067/FIRMS/MODIS/MCD14DL.NRT.006.

NOAA, 2017: U.S. time series. Climate at a Glance, National Centers for Environmental Information, accessed 2 February 2017. [Available online at http://www.ncdc.noaa.gov/cag/.]

Pacyna, J. M., and Coauthors, 2016: Current and future levels of mercury atmospheric pollution on a global scale. Atmos. Chem. Phys., 16, 12 495-12 511, doi:10.5194/acp-16-12495-2016.
Pirrone, N., and Coauthors, 2010: Global mercury emissions to the atmosphere from anthropogenic and natural sources. Atmos. Chem. Phys., 10, 5951-5964, doi:10.5194/acp-10-5951-2010.

Ren, X., and Coauthors, 2014: Mercury speciation at a coastal site in the northern Gulf of Mexico: Results from the Grand Bay intensive studies in summer 2010 and spring 2011. Atmosphere, 5, 230-251, doi:10.3390/atmos5020230.

_, and Coauthors, 2016: Atmospheric mercury measurements at a suburban site in the Mid-Atlantic United States: Interannual, seasonal and diurnal variations and source-receptor relationships. Atmos. Environ., 146, 141-152, doi:10.1016/ j.atmosenv.2016.08.028.

Rolph, G. D., 2017: READY: Real-time Environmental Applications and Display sYstem. NOAA Air Resources Laboratory. [Available online at http://www.ready.noaa.gov.]

Rutter, A. P., and Coauthors, 2009: In situ measurements of speciated atmospheric mercury and the identification of source regions in the Mexico City metropolitan area. Atmos. Chem. Phys., 9, 207-220, doi:10.5194/acp-9-207-2009.

Selin, N. E., 2014: Global change and mercury cycling: Challenges for implementing a global mercury treaty. Environ. Toxicol. Chem., 33, 1202-1210, doi:10.1002/etc.2374.

Sillman, S., F. J. Marsik, K. I. Al-Wali, G. J. Keeler, and M. S. Landis, 2007: Reactive mercury in the troposphere: Model formation and results for Florida, the northeastern United States, and the Atlantic Ocean. J. Geophys. Res., 112, D23305, doi:10.1029/2006JD008227.

Soerensen, A. L., H. Skov, D. J. Jacob, B. T. Soerensen, and M. S. Johnson, 2010: Global concentrations of gaseous elemental mercury and reactive gaseous mercury in the marine boundary layer. Environ. Sci. Technol., 44, 7425-7430, doi:10.1021/ es903839n.

Stein, A. F., R. R. Draxler, G. D. Rolph, B. J. B. Stunder, M. D. Cohen, and F. Ngan, 2015: NOAA's HYSPLIT atmospheric transport and dispersion modeling system. Bull. Amer. Meteor. Soc., 96, 2059-2077, doi:10.1175/BAMS-D-14-00110.1.

UNEP, 2013: Global Mercury Assessment 2013: Sources, emissions, releases, and environmental transport. UNEP Chemicals Branch, accessed 15 February 2017. [Available online at http://wedocs.unep.org//handle/20.500.11822/7984.]

Vincent, L. A., X. Zhang, R. D. Brown, Y. Feng, E. Mekis, E. J. Milewska, H. Wan, and X. L. Wang, 2015: Observed trends in Canada's climate and influence of low-frequency variability modes. J. Climate, 28, 4545-4560, doi:10.1175/ JCLI-D-14-00697.1.

Watson, J. G., L. W. A. Chen, J. C. Chow, P. Doraiswamy, and D. H. Lowenthal, 2008: Source apportionment: Findings from the U.S. Supersites Program. J. Air Waste Manage. Assoc., 58, 265-288, doi:10.3155/1047-3289.58.2.265.

Zhang, L., and Coauthors, 2016a: Mercury transformation and speciation in flue gases from anthropogenic emission sources: A critical review. Atmos. Chem. Phys., 16, 2417-2433, doi:10.5194/acp-16-2417-2016.

— deposition across North America. Environ. Sci. Technol., 50, 12 864-12 873, doi:10.1021/acs.est.6b04276.

Zhang, Y., and Coauthors, 2016c: Observed decrease in atmospheric mercury explained by global decline in anthropogenic emissions. Proc. Natl. Acad. Sci. USA, 113, 526-531, doi:10.1073/pnas.1516312113. 